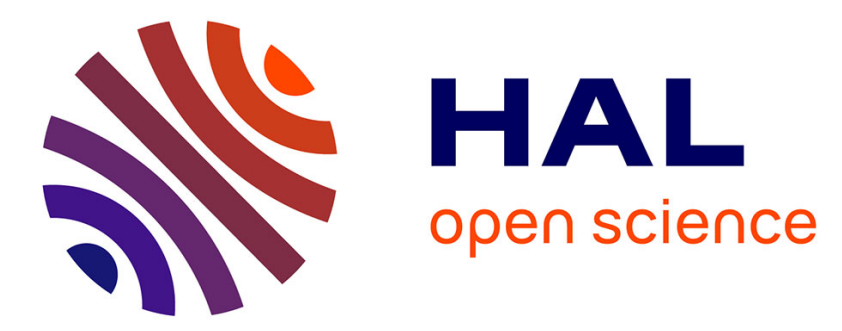

\title{
Environmental drivers of invertebrate population dynamics in Neotropical tank bromeliads
}

Olivier Dezerald, Céline Leroy, Bruno Corbara, Alain Dejean, Stanislas

Talaga, Régis Céréghino

\section{- To cite this version:}

Olivier Dezerald, Céline Leroy, Bruno Corbara, Alain Dejean, Stanislas Talaga, et al.. Environmental drivers of invertebrate population dynamics in Neotropical tank bromeliads. Freshwater Biology, 2017, 62 (2), pp.229-242. 10.1111/fwb.12862 . hal-01607779

\section{HAL Id: hal-01607779 \\ https://hal.science/hal-01607779}

Submitted on 19 Nov 2019

HAL is a multi-disciplinary open access archive for the deposit and dissemination of scientific research documents, whether they are published or not. The documents may come from teaching and research institutions in France or abroad, or from public or private research centers.
L'archive ouverte pluridisciplinaire HAL, est destinée au dépôt et à la diffusion de documents scientifiques de niveau recherche, publiés ou non, émanant des établissements d'enseignement et de recherche français ou étrangers, des laboratoires publics ou privés. 


\title{
Environmental drivers of invertebrate population dynamics in Neotropical tank bromeliads
}

\author{
OLIVIER DÉZERALD***, CÉLINE LEROY ${ }^{\dagger}$, BRUNO CORBARA ${ }^{\ddagger}$, , ALAIN DEJEAN* ${ }^{*}, * *$, \\ STANISLAS TALAGA* ${ }^{* \dagger \dagger}$ AND RÉGIS CÉRÉGHINO ${ }^{\uparrow, * *}$ \\ *CNRS, Ecologie des Forêts de Guyane (AgroParisTech, CIRAD, INRA, Université de Guyane, Université des Antilles), Kourou Cedex, \\ France \\ ${ }^{\dagger} I R D$, UMR AMAP (botAnique et Modélisation de l'Architecture des Plantes et des végétations), Montpellier Cedex 5, France \\ *Université Clermont Auvergne, Université Blaise Pascal, Clermont-Ferrand, France \\ ${ }^{\S}$ CNRS, Laboratoire Microorganismes: Génome et Environnement (UMR-CNRS 6023), Aubière, France \\ "Université de Toulouse, INP, UPS Laboratoire Ecologie Fonctionnelle et Environnement (ECOLAB), Toulouse, France \\ ${ }^{* *}$ CNRS, ECOLAB (UMR-CNRS 5245), Toulouse, France \\ †UUniversité de Guyane; UMR Écologie des Forêts de Guyane (AgroParisTech, CIRAD, CNRS, INRA, Université des Antilles), Kourou \\ Cedex, France
}

\section{SUMMARY}

1. Tank bromeliads form a conspicuous, yet neglected freshwater habitat in Neotropical forests. Recent studies driven by interests in medical entomology, fundamental aspects of bromeliad ecology and experimental research on food webs have, however, prompted increasing interest in bromeliad aquatic ecosystems. As yet, there is nothing in the literature about the life histories and environmental drivers of invertebrate population dynamics in tank bromeliads.

2. Based on fortnightly samples taken over one year, size frequency plots and individual dry masses allowed us to establish the life cycles and growth rates of the dominant aquatic invertebrates in a common bromeliad species of French Guiana. Linear mixed-effect models and Mantel tests were used to predict changes in density, biomass, and growth rates in relation to temperature, rainfall, humidity and detrital resources.

3. Annual variations in invertebrate densities and biomasses could be described according to three types of distribution: unimodal, bimodal or almost constant. Despite seasonal variations, precipitation, temperature, relative humidity and detritus concentration accounted significantly for changes in density and biomass, but we found no significant responses in growth rates of most invertebrate species. Species rather displayed non-seasonal life cycles with overlapping cohorts throughout the year. There was also a trend for delayed abundance peaks among congeneric species sharing similar functional traits, suggesting temporal partitioning of available resources.

4. Beyond novel knowledge, quantitative information on life histories is important to predict foodweb dynamics under the influence of external forcing and self-organisation. Our results suggest that changes in species distribution that will affect population dynamics through biotic interactions in space and/or time could have greater effects on food webs and ecosystem functioning than changes in environmental factors per se.

Keywords: food webs, freshwater invertebrates, growth rate, life history, rainforest

\section{Introduction}

In tropical forests, a substantial fraction of the fresh water available is impounded within phytotelmata, terrestrial plants that hold water in modified or specialised leaf axils, flower bracts or hollow parts (Kitching, 2000). Among them, tank bromeliads (Bromeliaceae) are conspicuous components of the Neotropical flora. These plants have

Correspondence: Olivier Dézerald, CNRS, Ecologie des Forêts de Guyane (AgroParisTech, CIRAD, INRA, Université de Guyane, Université des Antilles), Campus Agronomique, F-97379 Kourou cedex, France. E-mail: olivier.dezerald@gmail.com

HPresent address: Biology Department \& Center for Computational and Integrative Biology, Rutgers University, Camden, NJ, U.S.A. 
tightly interlocking leaves forming wells that collect rainwater from a few $\mathrm{mL}$ to $45 \mathrm{~L}$ per plant. Tank bromeliads occur from the soil to the canopy and can reach a density of up to 175000 individuals per hectare representing an estimated 50000 L of water (Sugden \& Robins, 1979; Richardson, 1999). They provide an aquatic habitat for specialised organisms ranging from prokaryotes to small vertebrates (Poelman \& Dicke, 2008; Frank \& Lounibos, 2009). Macroinvertebrates, mostly aquatic insect larvae, form the dominant part of the animal biomass inside tank bromeliads. The incoming detritus (e.g. leaf litter from overhanging trees, dead arthropods, faeces) constitutes the basic source of nutrients for the entire aquatic food web (Benzing, 2000; Leroy et al., 2016). Despite their number, ubiquity and wide geographical distribution, tank bromeliads (and plant-held waters in general) have received relatively little attention in comparison to other freshwater ecosystems. However, recent research driven by interests in medical entomology (some bromeliadbreeding mosquitoes are vectors of dengue or malaria; Talaga et al., 2015), fundamental aspects of phytotelm ecology (Brouard et al., 2011; 2012), or community- to ecosystem-level responses to climate change (Dézerald et al., 2015a; Trzcinski et al., 2016), has started to shed interesting new light on the bromeliad ecosystem structure and function.

Because they are small in size, can be exhaustively sampled, contain multiple trophic levels, and are linked via dispersal (constituting therefore metacommunities), tank-bromeliads are increasingly used as model systems to test ecological theory. Field observations and manipulative experiments have been used to address many ecosystem processes (Srivastava et al., 2004; Srivastava, 2006), from metacommunity and food web assembly rules (Armbruster, Hutchinson \& Cotgreave, 2002; Lecraw, Srivastava \& Romero, 2014; Petermann et al., 2015) to the relationships between environmental variability, biological diversity and ecosystem function (Srivastava \& Bell, 2009; Céréghino et al., 2011; Dézerald et al., 2013; Amundrud \& Srivastava, 2015; Hammill et al., 2015). However, most observational and experimental studies on bromeliad ecosystems captured short-term processes (a few days to a few weeks), when seasonal changes in the population structure and dynamics of co-occurring species can be significant (but see Richardson, Richardson \& Srivastava, 2015; for a study of inter-annual variations in invertebrate abundance).

Snapshot studies not only fail to integrate the turnover time of populations, but more importantly, they also tell us little about the environmental factors that dictate those life-history events (e.g. emergence, recruitment, periods of maximum growth denoting maximum resource use), which, in turn, determine interaction patterns among co-occurring species and energy flows within food webs (Bassar et al., 2016). Assuming that the dynamics of the local and regional environment select for life-history strategies that allow the best use of local resources in space and time (Southwood, 1977, 1988), information on life histories in relation to environmental fluctuations would, therefore, improve our ability to predict community- to ecosystem-level responses to environmental changes (Bassar et al., 2016). To date, however, to the best of our knowledge, there is nothing in the published literature about the life histories and growth patterns of bromeliad invertebrates.

In freshwater habitats, temperature, hydrology and food quality/quantity control the metabolic rates of invertebrates, thereby governing all aspects of population dynamics (e.g. growth rates, abundance-related patterns; Leung \& Dudgeon, 2011; Amarasekare \& Savage, 2012; Leung, Li \& Dudgeon, 2012; Amarasekare \& Coutinho, 2013). In temperate climates, seasonality creates marked and rather predictable environmental regimes, and accordingly, aquatic invertebrates exhibit a prevalence of seasonal life cycles with one to two generations per year, where cohorts as well as periods of maximum growth do not usually overlap among congeneric species (see various examples in Cayrou \& Céréghino, 2005). Conversely, tropical invertebrates show a prevalence of non-seasonal life cycles with several generations per year and faster growth (i.e. a series of overlapping cohorts and a wide range of size-classes that co-occur within a population; Merritt, Cummins \& Berg, 2008). This could be related to lower seasonality and higher mean annual temperature than in temperate climates. Nevertheless, water temperature was found to influence larval lifespan and to trigger life-history events (i.e. larval moults, pupation, emergence) in Toxorhynchites (Diptera: Culicidae) from French Guiana (Dézerald et al., 2015b). On the other hand, tropical climates have pronounced dry and wet seasons which could impart seasonality. For instance, a prolonged absence of precipitation was found to counter-select aquatic invertebrate taxa with longer generation times and to cause progressive declines in species abundance in tank bromeliads (Dézerald et al., 2015a). Finally, detrital resources in the form of fine or coarse particulate organic matter appeared as a significant driver of invertebrate abundance at various trophic levels (Armbruster et al., 2002; Jabiol et al., 2009), but we do not know whether seasonal changes in detrital inputs affect invertebrate abundance and growth patterns. 
Our study was conducted in French Guiana in a lowland rainforest typical of the Guiana Shield. Our aim was twofold. First, this is the first attempt to profile invertebrate life-history patterns in tank bromeliads. More specifically, we document the life cycles and growth rates of dominant bromeliad invertebrate species on the basis of fortnightly samples taken over one year. Second, we used linear mixed-effect models (LMMs) and Mantel tests to investigate which variables (i.e. temperature, rainfall, relative humidity, detritus quantity) are the best predictors of individual species' temporal dynamics in terms of density, biomass and growth rates. Assuming that (i) even slight changes in temperature affect metabolic activities in ectotherms, (ii) precipitation shows marked seasonal patterns and (iii) bromeliad food webs are fuelled by large amounts of detrital inputs and leaf fall shows some seasonality in the tropics (Wright \& Cornejo, 1990), we predicted that most of the variation in density, biomass and growth rates of individual species over the year would be explained either by temperature and/or precipitation patterns. Alternatively, the absence of environmentpopulation dynamics relationship would point towards the idea of a greater role for biological interaction effects on species' phenology.

\section{Methods}

\section{Study area and bromeliad species}

French Guiana is an overseas region of France located on the north-eastern coast of South America. About 96\% of its surface area $\left(83534 \mathrm{~km}^{2}\right)$ is covered by a remarkably species-rich equatorial forest (Bongers et al., 2001). This study was conducted in a lowland rainforest plot located near the Petit-Saut Dam, Sinnamary $\left(5^{\circ} 03^{\prime} 43^{\prime \prime} \mathrm{N}\right.$, $53^{\circ} 02^{\prime} 46^{\prime \prime} \mathrm{W}$; elevation $<80 \mathrm{~m}$ a.s.1.). The climate is tropical moist with $3000 \mathrm{~mm}$ of annual precipitation, little seasonal variation in air temperature (monthly averages range from 20.5 to $33.5^{\circ} \mathrm{C}$ ), and a relative humidity oscillating between 70 and $100 \%$. There is a major reduction in rainfall between July and December (the 'dry season') and another shorter and more irregular dry period in March, but prolonged droughts are rare (a mean maximum number of $17 \pm 5$ consecutive days without rainfall, averaged over the past 10 years; Dézerald et al., 2015a). The remaining months constitute the 'rainy season' (Fig. 1). Vriesea splendens (Bromeliaceae: Tillandsioideae) is the only tank bromeliad in the understorey of the area studied (c. $5000 \mathrm{~m}^{2}$ in size). Daily records of air temperature and rainfall over the entire study period were obtained from the nearby Petit-Saut Field station, Sinnamary.

\section{Sampling procedure}

Three well-developed $V$. splendens (excluding flowering and immature stages) were sampled at fortnightly intervals from April 2013 to April 2014 for a total of 72 plants (each group of three plants was sampled only once during the study). All of the plants selected were epiphytes growing at $<1 \mathrm{~m}$ above the ground or were secondary rooted on the soil. We first extracted all of the coarse detritus fallen from overhanging trees (e.g. leaf litter, twigs) from the rosette of each plant. The coarse detritus $(>1000 \mu \mathrm{m}$ in size) was rinsed in the field to collect the associated invertebrates. It was then dried at $60{ }^{\circ} \mathrm{C}$ for 3 days and weighed to obtain a dry mass (DM, g). To sample the water and aquatic invertebrates in the plants, we used a 10-mL micropipette with the end trimmed to widen the aperture. The actual volume $(V, \mathrm{~mL})$ was measured using a 250-mL graduated cylinder for the first water extraction; the wells were then refilled with rainwater and emptied again twice in order to maximise invertebrate sampling efficiency. Although less efficient than plant dissection (Jocque et al., 2010), we used this non-destructive sampling technique for ethical reasons and for consistency with other studies in the area (Céréghino et al., 2011; Dézerald et al., 2013). The sampled water was filtered through a $150-\mu \mathrm{m}$ mesh and the aquatic invertebrates were preserved in $4 \%$ formalin (final concentration). Once a plant was emptied, we measured its maximum water volume $\left(V_{\mathrm{m}}, \mathrm{mL}\right)$ as the difference between a known volume of water used to fill the bromeliad and the remaining water volume in the graduated cylinder when the bromeliad overflowed.

\section{Life cycles and growth rates}

Aquatic invertebrates were identified to species or morphospecies (hereafter, 'species'), enumerated in the laboratory and preserved in $70 \%$ ethanol (Table 1; see Appendix S1 in Supporting Information). Species density (ind $\mathrm{mL}^{-1}$ ) and biomass ( $\mathrm{mg} \mathrm{DM} \mathrm{mL}^{-1}$, see below for dry masses), and detrital resources $\left(\mathrm{g} \mathrm{DM} \mathrm{mL}^{-1}\right)$ were calculated using the maximum water volume $\left(V_{\mathrm{m}}\right)$ of the sampled plants. We used $V_{\mathrm{m}}$ because the actual volume $(V)$ is too sensitive to daily or even hourly changes in rainfall, and invertebrate populations do not respond quickly enough to these short-term environmental fluctuations to make $V$ meaningful for subsequent comparisons across sampling dates and seasons. 

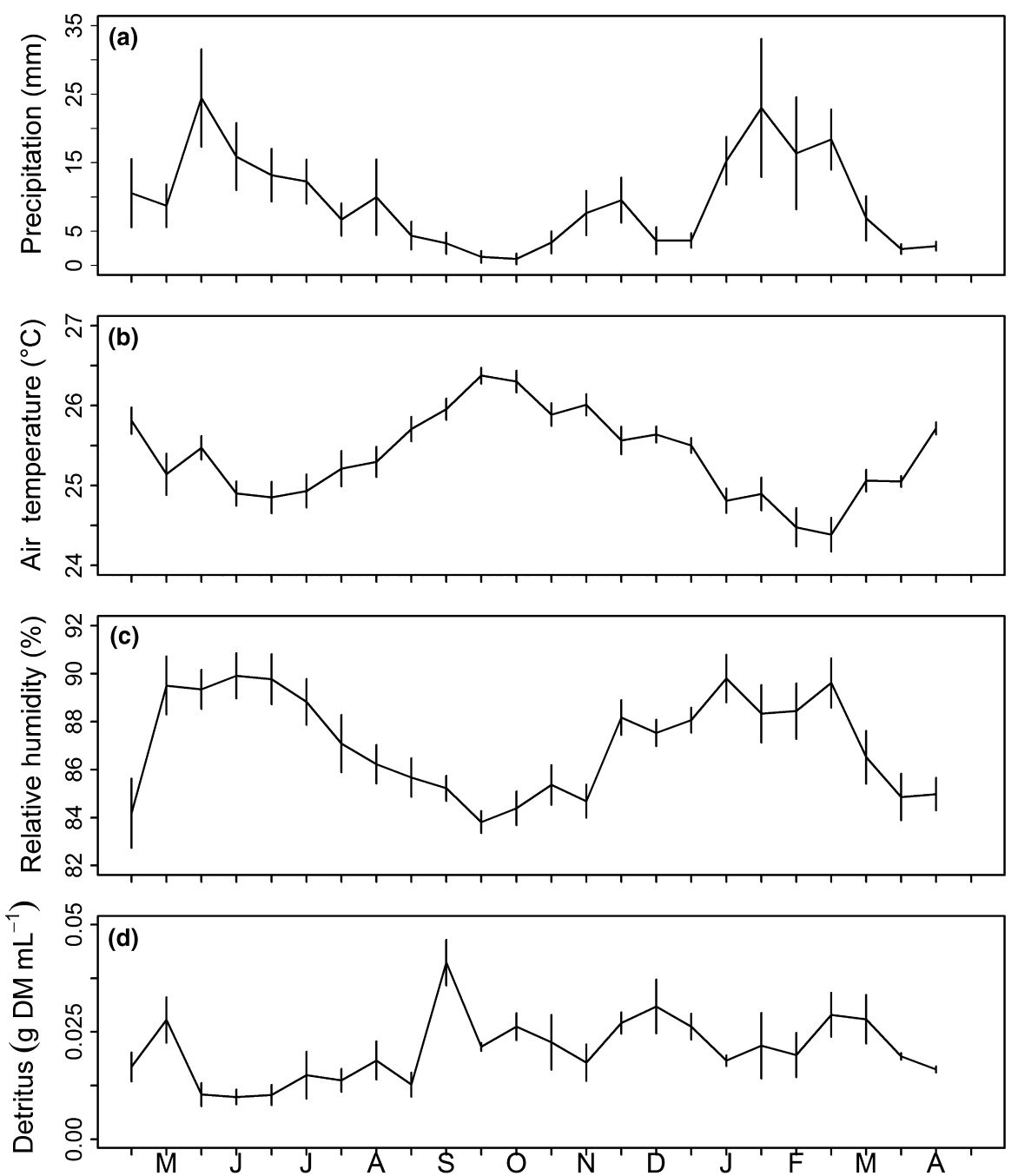

Fig. 1 Weekly fluctuations in mean (a) precipitation $(\mathrm{mm}),(\mathrm{b})$ air temperature $\left({ }^{\circ} \mathrm{C}\right)$, (c) relative humidity $(\%)$ and $(\mathrm{d})$ detrital concentration $\left(\mathrm{g} \mathrm{DM} \mathrm{mL} \mathrm{mL}^{-1}\right.$ ) from April 2013 to April 2014. Bars represent standard errors.
We note, however, that the sampled bromeliads were generally filled to $c$. $50 \%$ of their maximum volume $\left(V / V_{\max }=51.8 \pm 0.06 \%\right)$. We further estimated that our sampling procedure of three plants per sampling date allowed us to adequately describe the dynamics of the overall meta-population $(65.4 \%$ of the total species richness, and 98.6 and $98.3 \%$ of the mean annual density and biomass of the system; see Appendix S2 in Supporting Information).

All larvae were divided into $0.1 \mathrm{~mm}$-interval size classes based on measurements of non-deformable body parts: i.e. head capsule width, head capsule length or carapace length. Measurements were used to identify the larval instars, and to construct size-frequency plots for cohort and growth rate determinations. We could not, however, determine the life cycles of Aulophorus superterrenus (Haplotaxida: Naididae) and Brachycera spp. (Diptera) because these taxa do not have nondeformable, sclerotised body parts for reliable size measurements and subsequent cohort determination.
Cohorts sensu stricto are groups of individuals sharing the same hatching event during a particular time span. Here, different sets of three bromeliads within a bromeliad patch (typically a study area of $c .5000 \mathrm{~m}^{2}$ in size with a high density of bromeliads) were sampled every 2 weeks, and invertebrates were killed for subsequent measurements (size, dry mass). Therefore, we could not follow cohorts sensu stricto in individual bromeliads. Thus, we used samples of invertebrate metapopulations at the bromeliad patch level as proxy for the dynamics of populations at the level of an 'average bromeliad'. Since the larval development of any given cohort is synchronous among co-occurring bromeliads within our $5000 \mathrm{~m}^{2}$ study area, we determined 'cohorts' according to variations in the size structure (i.e. shifts in size classes in a time series of length frequency data) at the metapopulation level (Hynes \& Coleman, 1968; Stead, Schmid-Araya \& Hildrew, 2005; Benke \& Wallace, 2014). We also raised larvae in $50 \mathrm{~mL}$ tubes placed at ambient temperature to further confirm generation times from 
Table 1 Population estimates of the dominant aquatic invertebrates in the tank bromeliad Vriesea splendens. Da, mean annual density (ind $\mathrm{mL}^{-1}$ ); $\mathrm{Ba}$, mean annual biomass $\left(\mathrm{mg} \mathrm{mL}^{-1}\right)$; CPI, cohort production interval (days); $k$, growth rates (\% dry mass per day) ( $\left.\pm \mathrm{SE}\right)$.

\begin{tabular}{|c|c|c|c|c|}
\hline Taxa & $\mathrm{Da}$ & $\mathrm{Ba}$ & CPI & $k$ \\
\hline \multicolumn{5}{|l|}{ Coleoptera } \\
\hline \multicolumn{5}{|l|}{ Scirtidae } \\
\hline \multicolumn{5}{|l|}{ Diptera } \\
\hline \multicolumn{5}{|l|}{ Ceratopogonidae } \\
\hline Bezzia sp. & $1.2 \mathrm{e}-1 \pm 2.5 \mathrm{e}^{-2}$ & $2.4 \mathrm{e}-3 \pm 4.9 \mathrm{e}^{-4}$ & $28.8 \pm 2.1$ & $10.3 \pm 1.0$ \\
\hline Corethrella sp. & $1.4 \mathrm{e}-1 \pm 2.8 \mathrm{e}^{-2}$ & $3.3 \mathrm{e}-3 \pm 6.7 \mathrm{e}^{-4}$ & $10.0 \pm 1.3^{*}$ & $14.8 \pm 0.9$ \\
\hline \multicolumn{5}{|l|}{ Chironomidae } \\
\hline Orthocladiinae sp. & $1.8 \mathrm{e}-2 \pm 3.6 \mathrm{e}^{-3}$ & $5.7 \mathrm{e}-5 \pm 1.2 \mathrm{e}^{-5}$ & $21.0 \pm 3.7$ & $14.5 \pm 1.4$ \\
\hline \multicolumn{5}{|l|}{ Culicidae } \\
\hline Anopheles neivai & $2.3 \mathrm{e}-2 \pm 4.7 \mathrm{e}^{-3}$ & $1.3 \mathrm{e}-3 \pm 2.6 \mathrm{e}^{-4}$ & $27.0 \pm 5.6$ & $17.4 \pm 3.5$ \\
\hline Culex stonei & $3.0 \mathrm{e}-2 \pm 6.1 \mathrm{e}^{-3}$ & $1.1 \mathrm{e}-3 \pm 2.3 \mathrm{e}^{-4}$ & $13.5 \pm 2.5^{*}$ & $10.5 \pm 1.0$ \\
\hline \multicolumn{5}{|l|}{ Podocopida } \\
\hline \multicolumn{5}{|l|}{ Limnocytheridae } \\
\hline Elpidium bromeliarum & $7.1 \mathrm{e}-1 \pm 1.5 \mathrm{e}^{-1}$ & $1.3 \mathrm{e}-3 \pm 2.6 \mathrm{e}^{-4}$ & $70.0 \pm 5.0$ & $3.2 \pm 0.5$ \\
\hline
\end{tabular}

*Larvae raised in tubes at ambient temperature.

hatching to the last instar (hereafter, 'Cohort Production Interval', CPI) when cohorts could not be identified (i.e. Corethrella sp. and Culex stonei).

For each species, sets of 10-20 individuals from the different size classes were dried at $60{ }^{\circ} \mathrm{C}$ for $48 \mathrm{~h}$ and weighed to the nearest microgram using a microbalance (MX5; Mettler Toledo, Viroflay, France). Mean individual dry masses and densities per size class or larval instar were used to calculate biomass $\left(\mathrm{mg} \mathrm{mL}^{-1}\right)$ at each sampling date. Mean individual dry masses at each sampling date were log-transformed and used to represent the cohorts' growth patterns over time. A specific growth rate ( $k, \%$ dry mass per day) was calculated for each cohort using the following equation:

$$
k=100 \cdot\left(\frac{\log \left(\mathrm{DM}_{i 1} / \mathrm{DM}_{i 0}\right)}{t_{1}-t_{0}}\right)
$$

where $\mathrm{DM}_{i 0}$ and $\mathrm{DM}_{i 1}$ are the mean individual dry masses of the $i$ th cohort from hatching $\left(t_{0}\right)$ to the last instar $\left(t_{1}\right)$.

\section{Statistical analyses}

To determine the influence of environmental factors (e.g. precipitation, temperature, relative humidity and detritus concentration) on changes in the density and biomass of invertebrate species within bromeliads $(n=72)$, we used LMMs with 'sampling date' as a random variable (lme4-package in $\mathrm{R}$ software). We applied an arcsine transformation to all data (except densities of Elpidium bromeliarum that were log-transformed) to achieve normality. We created separate models for the density and biomass of each species (response variable) in relation to the four environmental factors (explanatory variables). To assess the overall significance of the models, we performed likelihood-ratio tests between the full (containing all four environmental variables and the random effect) and reduced models (only the random effect). Since we performed a separate model for 11 species belonging to the same meta-population (22 models in total for density and biomass), all $P$-values were corrected after Benjamini \& Hochberg (BH; Benjamini \& Hochberg, 1995). The significance of main effects in the significant models with the lowest Akaike information criterions was further evaluated using a type II ANOVA (lmerTest-package in $\mathrm{R}$ software). The conditional and marginal $R^{2}$ were calculated using the piecewiseSEMpackage in $\mathrm{R}$ software. We graphically assessed model validation (LMMs) and evaluated the normality of residuals using Shapiro tests.

In addition, for each species, two Mantel correlation tests were performed to assess relationships between growth rates (from 3 to $21 k$ values per species per year; 
except for $C$. stonei for which we only had two $k$ values), and the mean and coefficient of variation (CV) for temperature, precipitation, relative humidity and detrital concentrations over each cohort development time (vegan-package in $\mathrm{R}$ software). For instance, any given model contained the growth rate as a response variable and all mean value or $\mathrm{CV}$ for all environmental variables. This procedure allowed us to assess the overall significance of the effect of environmental variables on growth rates. Since multiple comparisons were performed on the same species (20 tests in total), we also applied the $\mathrm{BH}$ correction to adjust all $P$-values. We evaluated all statistical analyses at a 95\% confidence interval using R v. 3.1.2 (R Core Team, 2015).

\section{Results}

Temporal dynamics in density and biomass

The species pool at our study site consisted of 22 species (Appendix S1), of which 11 dominant species were present throughout the year in sufficient numbers to allow

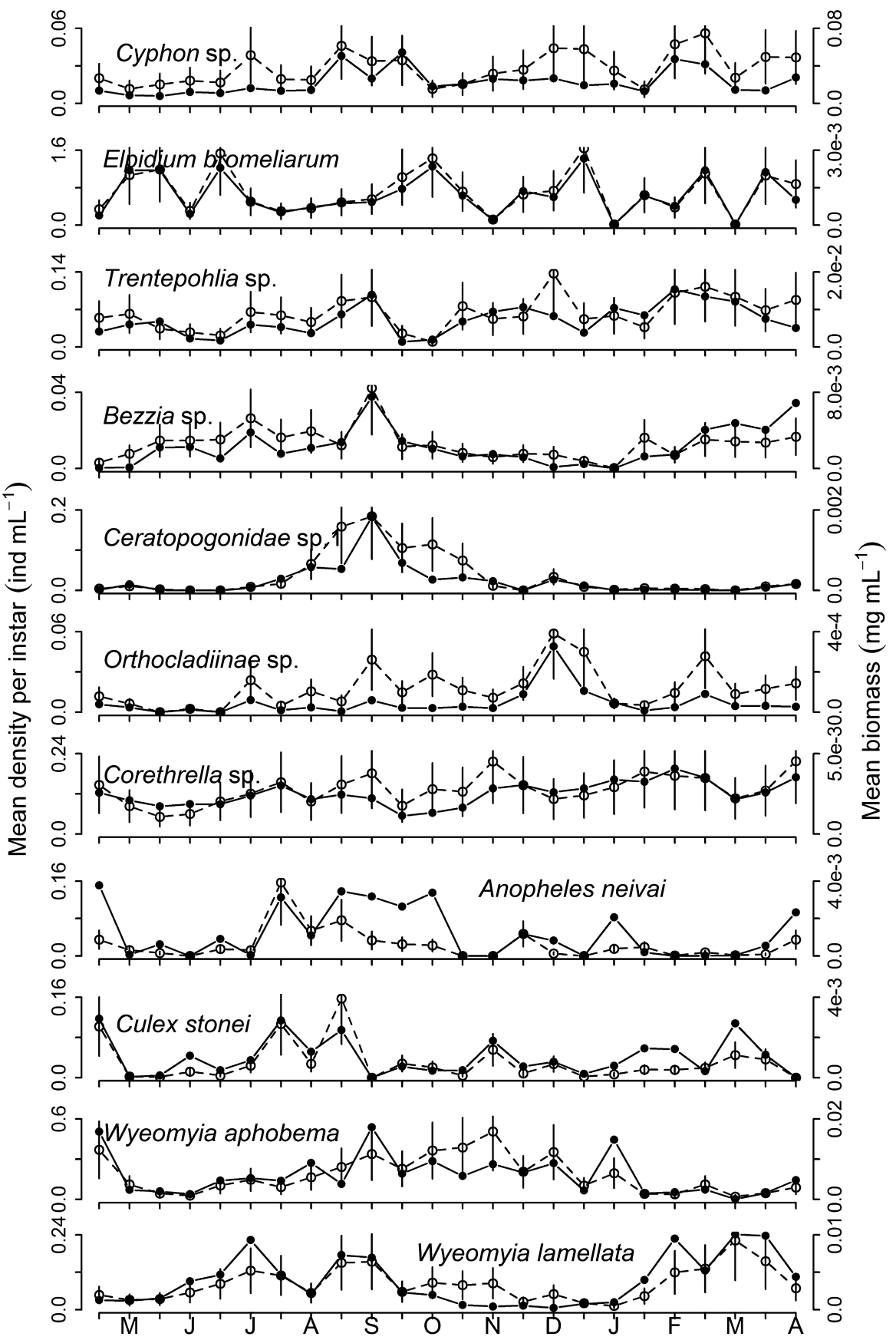

Fig. 2 Changes in the mean $( \pm \mathrm{SE})$ density (ind $\mathrm{mL}^{-1}$ ) and biomass ( $\mathrm{mg} \mathrm{mL}^{-1}$; solid and dotted lines respectively) of the 11 dominant species throughout the year (April 2013 to April 2014). 
the determination of their life cycles (Table 1). Overall, these species represented 65.2 and $89.1 \%$ of the mean annual density and biomass of the system respectively. These numbers reach 98.6 and $98.3 \%$ if we include two additional common taxa, namely A. superterrenus and Brachycera spp. (Appendix S2).

Overall, annual variations in invertebrate densities and biomasses were closely related, and could be divided into three types of distribution: unimodal, bimodal or almost constant. For the first type, several species showed a marked increase in density and biomass during the dry season (September through December), namely Wyeomyia aphobema, Ceratopogonidae sp.1, Orthocladiinae sp. and, to a lesser extent, Anopheles neivai (Fig. 2). Bezzia sp. and W. lamellata belonged to the second type of distribution, with two peaks: one in August-September and one in April. Finally, a few species did not show clear patterns in density or biomass (i.e. Corethrella sp., Cyphon sp. and Trentepohlia sp.; Fig. 2).
Despite clear seasonal changes in precipitation, and to a lesser extent temperature, we only found marginal effects of environmental conditions on the densities and biomasses of Ceratopogonidae sp.1, Trentepohlia sp. and W. lamellata, and on the densities of Orthocladiinae sp. and W. aphobema (Table 2). When further analysing the influence of each environmental variable (estimates and significance of main effects) on these five species, we found no significant variables influencing Ceratopogonidae $\quad$ sp.1 $\quad(F=0.39-2.04, \quad P=0.17-0.54$; Table 3). However, air temperature significantly and negatively influenced the density of Trentepohlia sp. $(F=5.6, P=0.03)$ and $W$. aphobema $(F=7.02, P=0.02)$ and the density and biomass of $W$. lamellata $(F=8.9$ and $19.6, P<0.001$ and $=0.01$ respectively). In addition, detrital concentration positively influenced the densities of Orthocladiinae sp. $(F=8.9, P=0.004)$ and the density and biomass of Trentepohlia sp. $(F=6.7, P=0.01$, and $F=8.4, \quad P=0.006$ respectively). Finally, the relative humidity only influenced the density and biomass of

Table 2 Influence of environmental factors on the density and biomass of invertebrate populations using linear mixed-effect models. We compared likelihoods of the full (including all predictors and random effect; see Methods section) and reduced (only random effect) models. Since we evaluated 22 models on the same populations, $P$-values before $(P)$ and after $(P c)$ the $\mathrm{BH}$ corrections are displayed. Only significant models (i.e. after the BH correction) with the lowest AIC were considered for further investigation (in bold). BH, Benjamini \& Hochberg; AIC, Akaike information criterions; Ds, mean density per sampling date; Bs, mean biomass per sampling date.

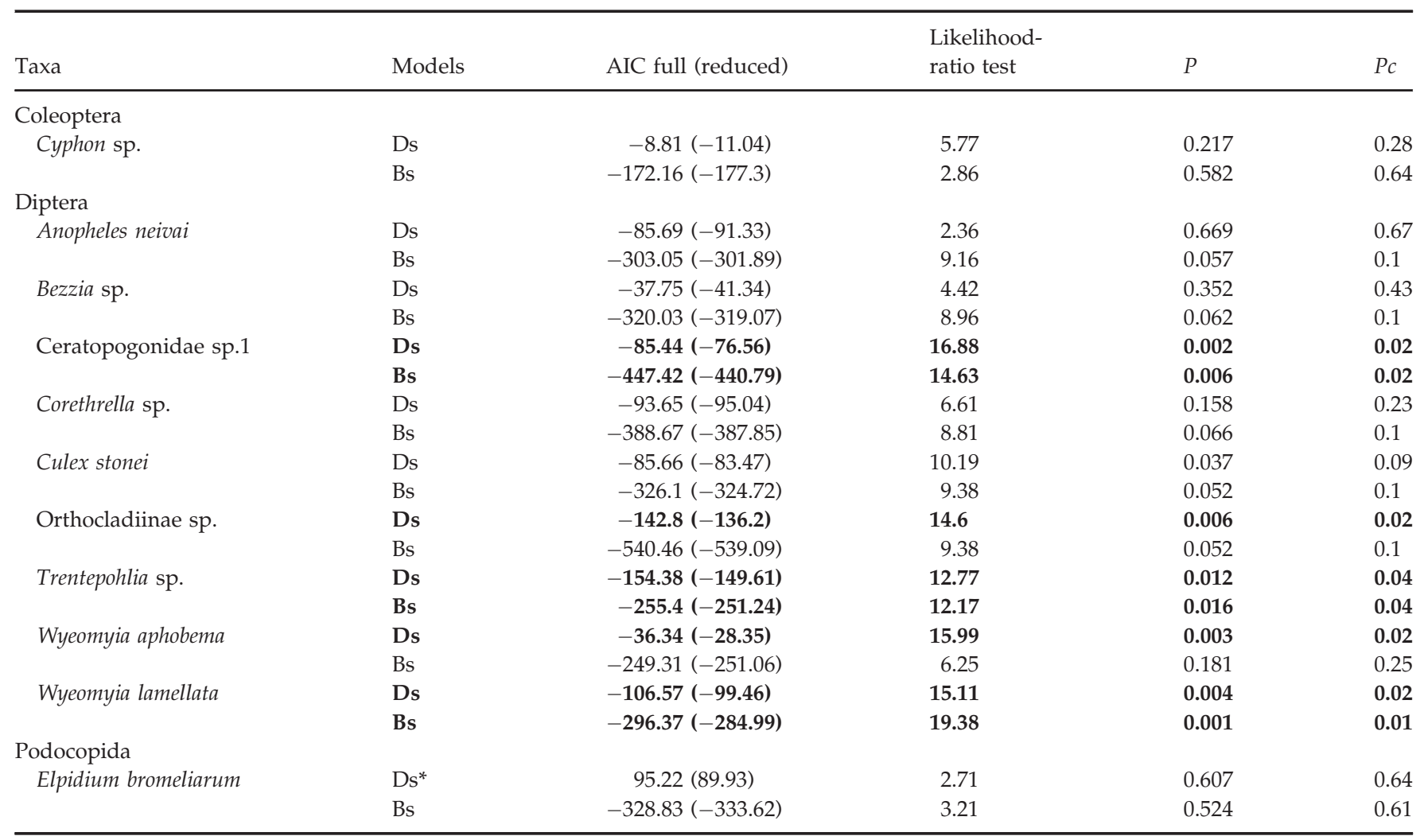

*In this model, the densities for Elpidium bromeliarum were log-transformed as we could not apply an arcsine transformation. 
Table 3 Influence of environmental factors (precipitation, temperature, humidity and detrital concentration) on the density and biomass of morphospecies for which the full models were significantly better than the reduced ones (see Table 2). Significant variables are highlighted in bold ( $F$ test; $P$-value). Estimates $\pm \mathrm{SE} ; \mathrm{RE}$, random effect ('sampling date').

\begin{tabular}{|c|c|c|c|c|c|c|c|}
\hline Models & Intercept & Precipitation & Temperature & Humidity & Detritus & Conditional $R^{2}$ & Marginal $R^{2}$ \\
\hline \multicolumn{8}{|c|}{ Ceratopogonidae sp.1 } \\
\hline $\begin{array}{l}\text { Density } \\
\text { RE: } 1.1 \mathrm{e}-01\end{array}$ & $-0.9 \pm 2.7$ & $\begin{array}{c}-0.003 \pm 4.5 \mathrm{e}^{-03} \\
(0.52 ; 0.48)\end{array}$ & $\begin{array}{l}0.09 \pm 6.1 \mathrm{e}^{-02} \\
(2.04 ; 0.17)\end{array}$ & $\begin{array}{c}-0.01 \pm 1.7 \mathrm{e}^{-02} \\
(0.61 ; 0.44)\end{array}$ & $\begin{array}{r}1.1 \pm 1.7 \\
(0.43 ; 0.51)\end{array}$ & 0.53 & 0.31 \\
\hline $\begin{array}{l}\text { Biomass } \\
\text { RE: } 8.4 \mathrm{e}-03\end{array}$ & $-0.06 \pm 2.4 \mathrm{e}^{-01}$ & $\begin{array}{c}-0.0004 \pm 4.0 \mathrm{e}^{-04} \\
(0.81 ; 0.38)\end{array}$ & $\begin{array}{l}0.006 \pm 5.4 \mathrm{e}^{-03} \\
(1.34 ; 0.26)\end{array}$ & $\begin{array}{c}-0.0009 \pm 1.5 \mathrm{e}^{-03} \\
(0.39 ; 0.54)\end{array}$ & $\begin{array}{l}0.1 \pm 1.4 \mathrm{e}^{-01} \\
(0.62 ; 0.43)\end{array}$ & 0.59 & 0.3 \\
\hline \multicolumn{8}{|c|}{ Orthocladiinae sp. } \\
\hline \multicolumn{8}{|l|}{ Trentepohlia sp. } \\
\hline $\begin{array}{l}\text { Density } \\
\text { RE: } 6.8 \mathrm{e}-02\end{array}$ & $3.2 \pm 1.6$ & $\begin{array}{c}-0.003 \pm 2.8 \mathrm{e}^{-03} \\
(0.88 ; 0.36)\end{array}$ & $\begin{array}{c}-0.09 \pm 3.7 \mathrm{e}^{-02} \\
(5.64 ; 0.03)\end{array}$ & $\begin{array}{c}-0.009 \pm 1.0 \mathrm{e}^{-02} \\
(0.7 ; 0.41)\end{array}$ & $\begin{array}{r}2.8 \pm 1.1 \\
(6.68 ; 0.01)\end{array}$ & 0.43 & 0.19 \\
\hline $\begin{array}{l}\text { Biomass } \\
\text { RE: } 3.8 \mathrm{e}-02\end{array}$ & $1.3 \pm 6.3 \mathrm{e}^{-01}$ & $\begin{array}{l}0.001 \pm 1.1 \mathrm{e}^{-03} \\
(1.75 ; 0.2)\end{array}$ & $\begin{array}{l}-0.03 \pm 1.4 \mathrm{e}^{-02} \\
(3.95 ; 0.06)\end{array}$ & $\begin{array}{c}-0.006 \pm 4.0 \mathrm{e}^{-03} \\
(2.11 ; 0.16)\end{array}$ & $\begin{array}{l}1.5 \pm 5.0 \mathrm{e}^{-01} \\
(8.42 ; 0.006)\end{array}$ & 0.19 & 0.17 \\
\hline \multicolumn{8}{|c|}{ Wyeomyia aphobema } \\
\hline \multicolumn{8}{|c|}{ Wyeomyia lamellata } \\
\hline $\begin{array}{l}\text { Biomass } \\
\text { RE: } 2.7 \mathrm{e}-02\end{array}$ & $2.4 \pm 5.6 \mathrm{e}^{-01}$ & $\begin{array}{c}-0.0008 \pm 9.0 \mathrm{e}^{-04} \\
(0.69 ; 0.41)\end{array}$ & $\begin{array}{l}-0.06 \pm 1.3 \mathrm{e}^{-02} \\
(19.62 ;<0.001)\end{array}$ & $\begin{array}{c}-0.01 \pm 3.6 \mathrm{e}^{-03} \\
(7.99 ; 0.01)\end{array}$ & $\begin{array}{l}-0.6 \pm 4.0 \mathrm{e}^{-01} \\
(2.23 ; 0.14)\end{array}$ & 0.44 & 0.3 \\
\hline
\end{tabular}

W. lamellata $(F=6.6, \quad P=0.02$, and $F=8.0, \quad P=0.01$ respectively; Table 3$)$.

\section{Growth patterns of dominant species}

The life cycles of the 11 dominant species can be divided into two main groups based on the number of generations per year and the development time from hatching to last instar. For all species, the growth patterns (mean individual dry mass versus time) deduced from our interpretations of size-frequency plots repeated themselves over the year (Figs 3 \& 4). The first group (hereafter 'slower life histories') included three species with relatively long larval lifespans (CPI $=1.5-3$ months) and accordingly fewer than six generations per year; namely, Cyphon sp., Trentepohlia sp. and Elpidium bromeliarum (Fig. 3 and Table 1). The range in sizes was vast at any point in time throughout the year suggesting that all larval instars were generally present at all times. Despite the overlapping of generations, we were able to identify cohorts and development patterns. Hatching occurred throughout the year, except in October for Trentepohlia sp., and except during the dry season (mid-August to mid-December) for Cyphon sp. and E. bromeliarum. During the rainy season (early May to August), the cohorts of E. bromeliarum were not distinguishable. The second group (hereafter 'faster life histories') included the remaining eight species. These fast-growing species were all dipterans with three or four larval instars, a short larval lifespan (CPI = 10-30 days), and up to 22 generations per year. For the culicids W. aphobema and $W$. lamellata, instars were found throughout the year (Fig. 3). The size-frequency and growth plots suggest that these species had 13 and 22 generations per year respectively (Fig. 3). The larvae grew quickly and emerged about 3 weeks after hatching all year round, so that there was no seasonal pattern of emergence. The culicids A. neivai and C. stonei had different developmental patterns where early instars (denoting hatching) were mostly present from July to September. Larvae grew from instar 1 to instar 4 within 1-1.5 months, but then seemed to remain at instar 4 over 1-2 months, so that these species presumably had $c$. five generations per year. Bezzia sp. and Corethrella sp. also had four larval instars and 13 and 15 generations per year, respectively, so that all larval instars were present throughout the year. For Corethrella sp., pupae were also remarkably frequent. Orthocladiinae sp. and Ceratopogonidae sp.1 had three instars. The identifiable cohorts had a CPI of 20-27 days, suggesting the occurrence of 12-15 generations per year. We noted, however, that Orthocladiinae sp. last instars were missing from our samples from April to November (Fig. 4).

On average, growth rates $(k)$ ranged from 10 to $20 \%$ increase in dry mass per day for species with 'faster life histories', whereas they were between 3 and $7 \%$ dry 
Fig. 3 Life histories of 11 dominant invertebrate species in the tank bromeliad Vriesea splendens. Frequency distribution of all larval instars were deduced from head capsule width measurements at each sampling date (from April 2013 to April 2014) except for Elpidium bromeliarum (carapace length) and Bezzia sp. (head capsule length). The asterisks indicate occurrence of pupae in the samples. For each sampling date, bars total $100 \%$.

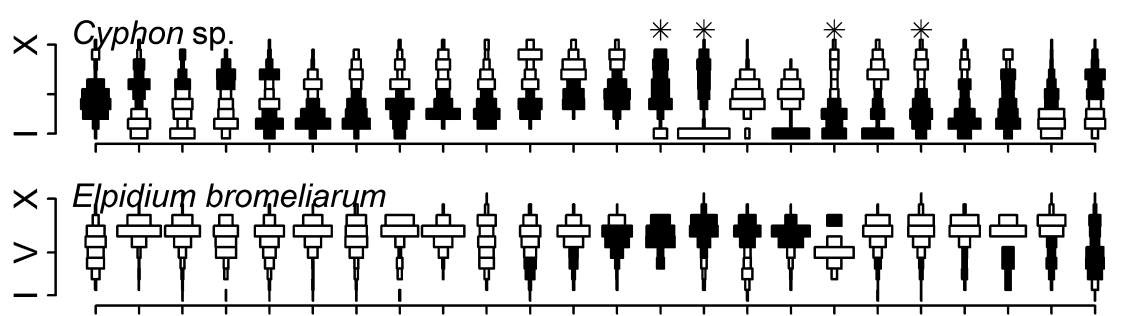

Trentepohlia sp.

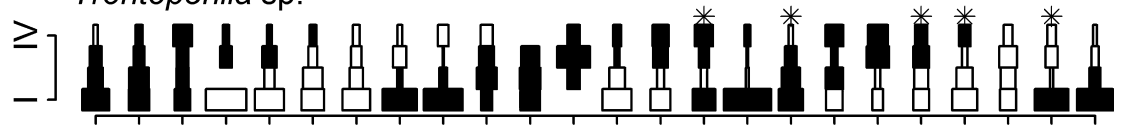
Bezzia sp.
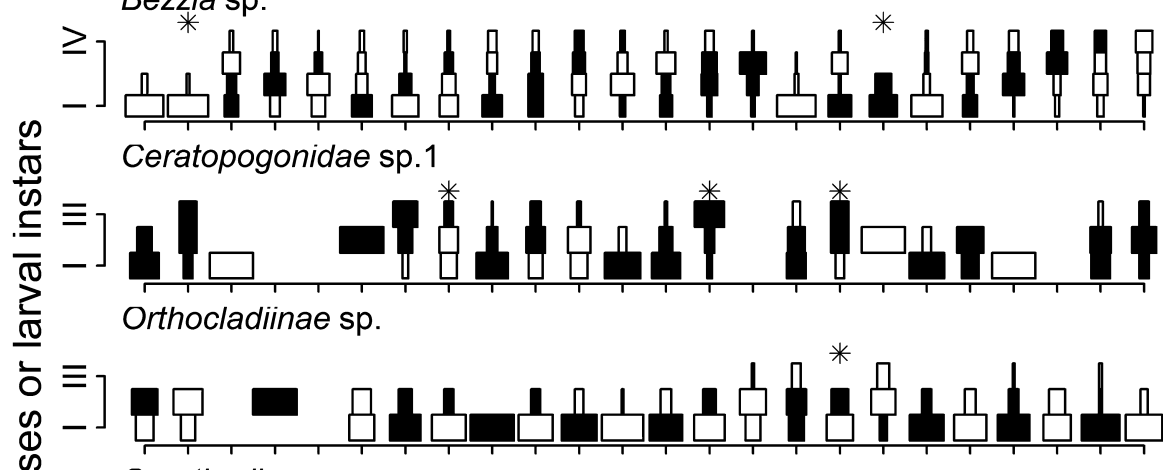
( $\quad$ Corethrella sp.

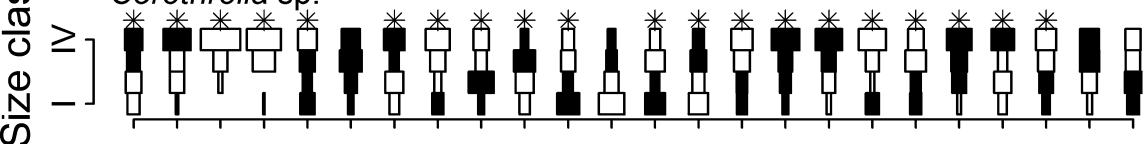

Anopheles neivai

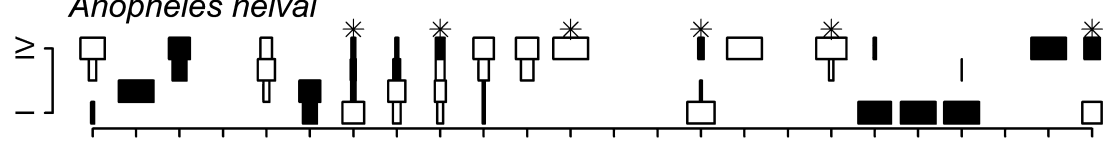

Culex stonei

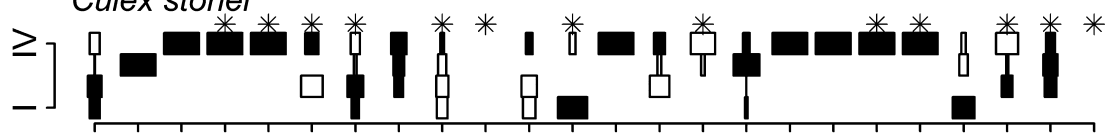
Wyeomyia aphobema

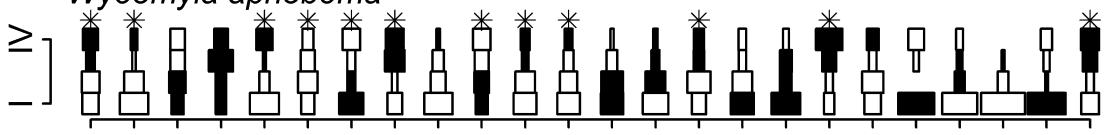
Wyeomyia lamellata

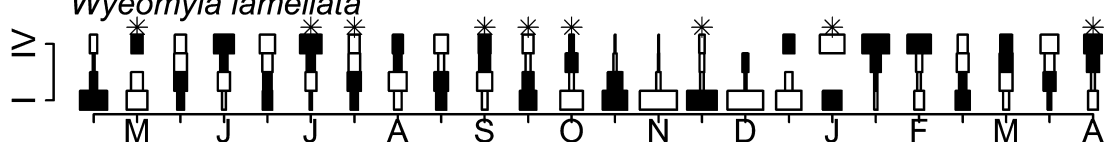

mass per day for species with 'slower life histories' (e.g. Cyphon sp., E. bromeliarum and Trentepohlia sp., Fig. 4, Table 1). We noted that the Cyphon sp. and Trentepohlia sp. larvae that hatched during the dry season tended to grow faster than larvae that hatched during the rainy season (Fig. 4). A total of 20 Mantel correlation tests were performed on the growth rates of the dominant species (except the culicid C. stonei for which only two cohorts were identified) versus the mean and CV for temperature, precipitation, humidity and detrital concentration. We found, however, no significant relationships between the growth rates of the various species and these environmental variables, except for Anopheles neivai (Table 4), but this latter relationship did not remain significant after the $\mathrm{BH}$ correction.

\section{Discussion}

Seasonal changes in air temperature, rainfall, relative humidity and detrital concentration were deemed 


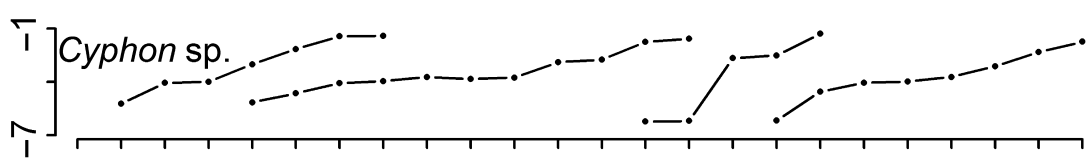

n

ค
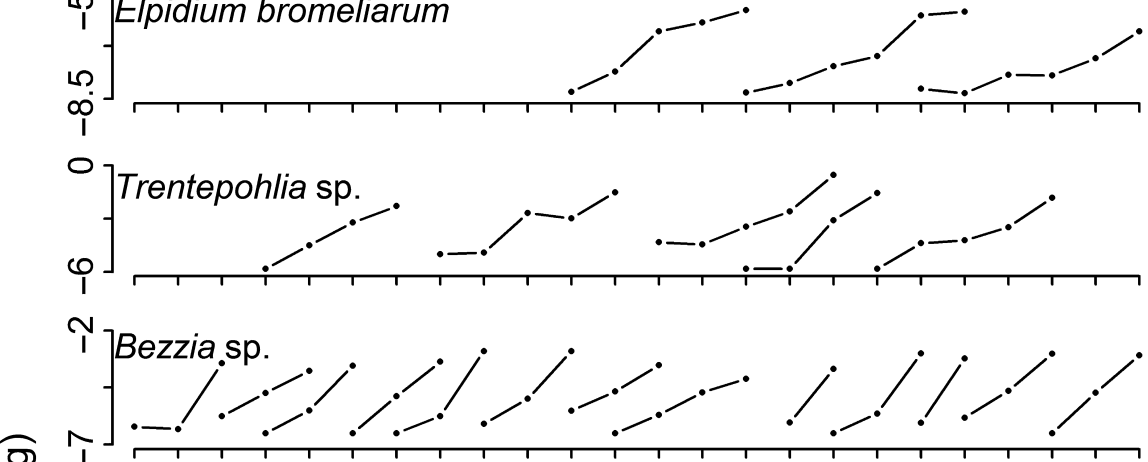

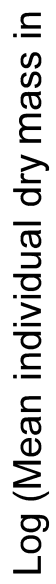

Ti
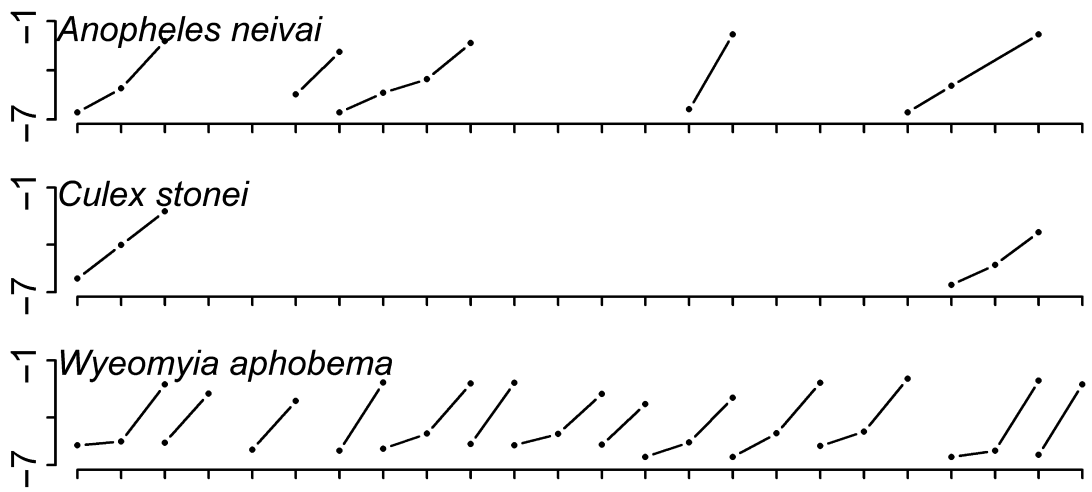

† Wyẹomyia lamellata

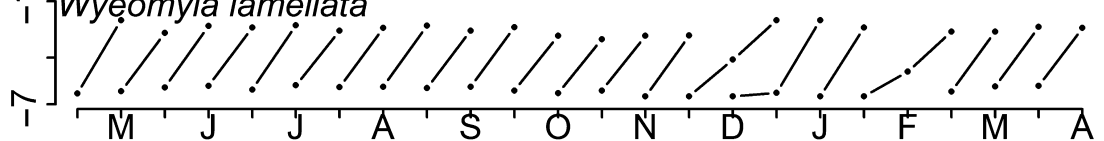

Fig. 4 Mean individual dry mass (mg, natural log-transformed) as a function of time, depicting the growth patterns of cohorts of the 11 dominant species (April 2013 to April 2014). potential drivers of invertebrate population dynamics in small freshwater pools in rainforest environments. There was, however, a limited or modest environmental signal in the biomass and density models, while growth rates showed no significant response to the study variables. We see two non-mutually exclusive explanations for this mismatch in the response of two distinct population parameters to environmental conditions. First, the thermal amplitudes recorded in this study may not have been sufficiently variables to generate metabolic responses. This suggests that maturation processes is under strong developmental and evolutionary constraints, whereas densities/biomasses are rather determined by short-term ecological processes such as oviposition behaviour of terrestrial adult stages (which was not evaluated in this study). Second, the carrying 
Table 4 Influence of the mean and CV of environmental factors (e.g. temperature, precipitation, humidity and detrital concentration) on the growth rates of the dominant taxa. CV, coefficient of variation; $\mathrm{Nb} K$, number of $K$ values or sample size.

\begin{tabular}{|c|c|c|c|c|}
\hline Taxa & Mantel test & $\mathrm{Nb} K$ & Mantel $R$ & $P$ \\
\hline \multicolumn{5}{|l|}{ Coleoptera } \\
\hline \multirow{2}{*}{ Cyphon sp. } & Mean & 4 & 0.07 & 0.54 \\
\hline & $\mathrm{CV}$ & & 0.73 & 0.17 \\
\hline \multicolumn{5}{|l|}{ Diptera } \\
\hline \multirow[t]{2}{*}{ Anopheles neivai } & Mean & 5 & 0.33 & 0.02 \\
\hline & $\mathrm{CV}$ & & 0.24 & 0.27 \\
\hline \multirow[t]{2}{*}{ Bezzia sp. } & Mean & 13 & 0.02 & 0.38 \\
\hline & $\mathrm{CV}$ & & -0.02 & 0.55 \\
\hline \multirow[t]{2}{*}{ Ceratopogonidae sp.1 } & Mean & 5 & 0.16 & 0.32 \\
\hline & $\mathrm{CV}$ & & -0.2 & 0.8 \\
\hline \multirow[t]{2}{*}{ Corethrella sp. } & Mean & 15 & 0.12 & 0.08 \\
\hline & $\mathrm{CV}$ & & 0.13 & 0.07 \\
\hline \multirow[t]{2}{*}{ Orthocladiinae sp. } & Mean & 5 & 0.05 & 0.43 \\
\hline & $\mathrm{CV}$ & & 0.51 & 0.15 \\
\hline \multirow[t]{2}{*}{ Trentepohlia sp. } & Mean & 5 & -0.07 & 0.57 \\
\hline & $\mathrm{CV}$ & & 0.2 & 0.23 \\
\hline \multirow[t]{2}{*}{ Wyeomyia aphobema } & Mean & 13 & -0.02 & 0.54 \\
\hline & $\mathrm{CV}$ & & 0.1 & 0.14 \\
\hline \multirow[t]{2}{*}{ Wyeomyia lamellata } & Mean & 21 & -0.06 & 0.86 \\
\hline & $\mathrm{CV}$ & & -0.05 & 0.7 \\
\hline \multicolumn{5}{|l|}{ Podocopida } \\
\hline \multirow[t]{2}{*}{ Elpidium bromeliarum } & Mean & 3 & 0.33 & 0.5 \\
\hline & $\mathrm{CV}$ & & -1.0 & 1.0 \\
\hline
\end{tabular}

capacity of the system (a major driver of aquatic invertebrate abundance; Spooner \& Vaughn, 2006) was held almost constant both by our sampling scheme (plants were matched by their size) and by bromeliad hydrology. The morphology of tank bromeliads acts as a buffer against variations in precipitations (Trzcinski et al., 2016), thus ensuring hydrological stability; here, bromeliads were generally filled to $c$. $50 \%$ of their maximum volume throughout the year. If environmental conditions never exceeded the physiological regulation capabilities of species (weak thermal amplitudes, sufficient amounts of water despite fluctuations), then only extreme events would significantly alter densities, biomasses and growth rates, or eventually trigger the production of resistant forms (e.g. desiccation-resistant eggs or cyst). In a recent study at the same site (Dézerald et al., 2015a), we experimentally sheltered $V$. splendens from the rain and noted that it takes 7 weeks for the tanks of the bromeliads to completely dry out (leaf rosettes form complex reservoirs that buffer changes in precipitation), whereas a maximum number of $17 \pm 5.3( \pm \mathrm{SE})$ consecutive days without rainfall was recorded at the study site over the past 10 years (the maximum number of rain free days per year averaged over the last decade). In other words, our invertebrates were never subjected to drought stress.
All species had non-seasonal life cycles with overlapping generations showing repeated growth patterns throughout the year. We, however, did note two types of life-history strategies which may be related to other functional traits of bromeliad invertebrates (Céréghino et al., 2011). Species with a larval lifespan $>1.5$ months and $<6$ generations per year (i.e. Cyphon sp., Trentepohlia sp., E. bromeliarum) have legs or pseudopods that enable them to crawl onto the aerial parts of bromeliads to seek food and/or more suitable leaf wells (Dézerald et al., 2015a; O. Dézerald, pers. obs.). This also applies to odonate larvae (Amundrud \& Srivastava, 2015), although we were not able to study their life cycle in detail. These functional traits confer more ecological flexibility towards habitat variability compared to physiological traits in which they trigger immediate responses to locally unsuitable conditions (e.g. avoidance, mitigation, short-range migrations). As a consequence, these species can channel more energy into the formation of body mass over longer time periods (i.e. slower growth and higher body mass). Conversely, species that can only swim in the water column or crawl on the bottom (e.g. culicids, chironomids, Corethrella sp.) are more exposed to habitat stochasticity (i.e. they cannot escape from their wells), and so channel more energy into fast larval growth and short hatching-to-emergence time (i.e. shorter lifespan $<1.5$ months with $>6$ generations per year, higher growth rates and lower body masses).

Competitive and/or predator-prey interactions - two additional aspects that were not considered in this study - could eventually account for temporal changes in density and biomass (Bassar et al., 2016), especially in small, contained habitats (Azevedo, Kraenkel \& Pamplona Da Silva, 2012). Delayed peaks in abundance notably facilitate the coexistence of species that have similar functional traits via the temporal partitioning of the food and habitat resources (Adam et al., 2015). On visual inspection of Fig. 2 herein, we cautiously suggest that delayed peaks in densities and biomasses are apparent in Culicidae species, e.g. in the congeneric species W. aphobema and W. lamellata. Also, A. neivai and C. stonei peaked in density before W. aphobema and $W$. lamellata. Although they are more phylogenetically distant from each other, the detritivores Ceratopogonidae sp.1 and Orthocladiinae sp. (similar body size, both feeding on fine detritus at the bottom of the wells) showed temporally segregated peaks in density and biomass. The significance of these patterns would, however, deserve further analyses using appropriate null models (and probably more field data to reach a higher replication), to properly test the hypothesis of temporal 
niche displacement and its potential role in shaping bromeliad invertebrate population dynamics. The dominant predators (i.e. Bezzia sp., Corethrella sp.) were small in size and had 13-15 fast-growing cohorts per year, so their biomass turnover was superior or similar to the biomass turnover of their potential prey. In addition, mean annual biomass estimates (Table 1) suggest a community structure characterised by a bottom-heavy trophic pyramid where predators represent only $11.1 \%$ of the total annual biomass. These data point towards the idea of a weak top-down control of density and biomass patterns of prey populations. This situation contrasts, however, with other geographical areas of the Neotropics (e.g. Costa Rica, Brazil) where bromeliads commonly host a large-bodied predator (an odonate) that exerts a strong top-down control over detritivores to the point that the biomass pyramids of these communities are top-heavy (Petermann et al., 2015).

The present work represents the first quantitative study of the life-history patterns of tank bromeliad invertebrates and of the relationships between invertebrate population dynamics and environmental fluctuations in the broader context of an eastern Amazonian forest. Beyond providing novel knowledge, quantitative information on life histories is of vital importance for predicting food-web dynamics under the influence of both external forces (i.e. natural variability, disturbance) and self-organisation (i.e. functional traits, biological interactions). Along the northern and eastern coasts of South America, anthropogenic climate change is predicted to increase the frequency and intensity of extreme climatic events such as prolonged dry seasons (IPCC, 2013; Stott, 2016). In this context, our results suggest that changes in species distribution that will affect population dynamics through biotic interactions in space and/or time could have greater effects on food webs and ecosystem functions than changes in environmental factors per se (see also Trzcinski et al., 2016). In the light of ongoing research that makes successful use of bromeliad food webs to test ecological theory (Farjalla et al., 2012; Marino, Srivastava \& Farjalla, 2013; Amundrud \& Srivastava, 2015; Trzcinski et al., 2016), we therefore encourage further studies of bromeliad invertebrate population dynamics, with emphasis on the life histories of large predators in those biogeographical areas characterised by top-heavy trophic pyramids and strong topdown controls.

\section{Acknowledgments}

We thank Frédéric Petitclerc, Clément Andrzejewski, and Arthur Compin for field assistance, the Laboratoire
Environnement Hydreco (Petit-Saut) for providing logistical support, and Andrea Yockey-Dejean for proofreading the English text. We are grateful to the associate editor Dr Benoît Demars, Dr Kurt Trzcinski, Dr Diane Srivastava, and one anonymous reviewer for providing insightful comments on an earlier version of the manuscript. Financial support was provided by the Agence Nationale de la Recherche throught the Rainwebs project (grant ANR-12-BSV7-0022-01) and an Investissement d'Avenir grant (Labex CEBA, ref. ANR-10-LABX-25-01). OD and ST were funded by a PhD scholarship (French Centre National de la Recherche Scientifique and the Fond Social Européen for OD; Université Antilles-Guyane for ST).

\section{References}

Adam T.C., Kelley M., Ruttenberg B.I. \& Burkepile D.E. (2015) Resource partitioning along multiple niche axes drives functional diversity in parrotfishes on Caribbean coral reefs. Oecologia, 179, 1173-1185.

Amarasekare P. \& Coutinho R.M. (2013) The intrinsic growth rate as a predictor of population viability under climate warming. Journal of Animal Ecology, 82, 1240-1253.

Amarasekare P. \& Savage V. (2012) A framework for elucidating the temperature dependence of fitness. The American Naturalist, 179, 178-191.

Amundrud S.L. \& Srivastava D.S. (2015) Drought sensitivity predicts habitat size sensitivity in an aquatic ecosystem. Ecology, 96, 1957-1965.

Armbruster P., Hutchinson R.A. \& Cotgreave P. (2002) Factors influencing community structure in a South American tank bromeliad fauna. Oikos, 96, 225-234.

Azevedo F., Kraenkel R.A. \& Pamplona Da Silva D.J. (2012) Competitive release and area effects. Ecological Complexity, 11, 154-159.

Bassar R.D., Childs D.Z., Rees M., Tuljapurkar S., Reznick D.N. \& Coulson T. (2016) The effects of asymmetric competition on the life history of Trinidadian guppies. Ecology Letters, 19, 268-278.

Benjamini Y. \& Hochberg Y. (1995) Controlling the false discovery rate: a practical and powerful approach to multiple testing. Journal of the Royal Statistical Society Series BMethodological, 57, 289-300.

Benke A.C. \& Wallace B.J. (2014) High secondary production in a Coastal Plain river is dominated by snag invertebrates and fuelled mainly by amorphous detritus. Freshwater Biology, 60, 236-255.

Benzing D.H. (2000) Bromeliaceae: Profile of an Adaptive Radiation. Cambridge University Press, Cambridge.

Bongers F., Charles-Dominique P., Forget P.-M. \& Théry M. (2001) Nouragues: Dynamics and Plant-Animal Interactions in a Neotropical Rainforest. Kluwer Academic Publishers, Boston.

(C) 2016 John Wiley \& Sons Ltd, Freshwater Biology, 62, 229-242 
Brouard O., Céréghino R., Corbara B., Leroy C., Pélozuelo L., Dejean A. et al. (2012) Understorey environments influence functional diversity in tank-bromeliad ecosystems. Freshwater Biology, 57, 815-823.

Brouard O., Le Jeune A.H., Leroy C., Céréghino R., Roux O., Pélozuelo L. et al. (2011) Are algae relevant to the detritusbased food web in tank-bromeliads? PLOS ONE, 6, e20129.

Cayrou J. \& Céréghino R. (2005) Life-cycle phenology of some aquatic insects: implications for pond conservation. Aquatic Conservation: Marine and Freshwater Ecosystems, 15, 559-571.

Céréghino R., Leroy C., Carrias J.F., Pélozuelo L., Ségura C., Bosc C. et al. (2011) Ant-plant mutualisms promote functional diversity in phytotelm communities. Functional Ecology, 25, 954-963.

Dézerald O., Céréghino R., Corbara B., Dejean A. \& Leroy C. (2015a) Functional trait responses of aquatic macroinvertebrates to simulated drought in a Neotropical bromeliad ecosystem. Freshwater Biology, 60, 1917-1929.

Dézerald O., Céréghino R., Corbara B., Dejean A. \& Leroy C. (2015b) Temperature:diet interactions affect survival through foraging behavior in a bromeliad-dwelling predator. Biotropica, 47, 569-578.

Dézerald O., Leroy C., Corbara B., Carrias J.-F., Pélozuelo L., Dejean A. et al. (2013) Food-web structure in relation to environmental gradients and predator-prey ratios in tank-bromeliad ecosystems. PLoS ONE, 8, e71735.

Farjalla V.F., Srivastava D.S., Marino N.A.C., Azevedo F.D., Dib V., Lopes P.M. et al. (2012) Ecological determinism increases with organism size. Ecology, 93, 1752-1759.

Frank J.H. \& Lounibos L.P. (2009) Insects and allies associated with bromeliads: a review. Terrestrial Arthropod Reviews, 1, 125-153.

Hammill E., Atwood T.B., Corvalan P. \& Srivastava D.S. (2015) Behavioural responses to predation may explain shifts in community structure. Freshwater Biology, 60, 125-135.

Hynes H.B.N. \& Coleman M.J. (1968) A simple method of assessing the annual production of stream benthos. Limnology and Oceanography, 13, 569-573.

IPCC. (2013) Climate Change 2013: The Physical Science Basis. Working Group I Contribution to the IPCC. Fifth Assessment Report. Cambridge University Press, Cambridge. Available at: http://www.ipcc.ch/report/ar5/wg1.

Jabiol J., Corbara B., Dejean A. \& Céréghino R. (2009) Structure of aquatic insect communities in tank-bromeliads in a East-Amazonian rainforest in French Guiana. Forest Ecology and Management, 257, 351-360.

Jocqué M., Kernahan A., Nobes A., Willians C. \& Field R. (2010) How effective are non-destructive sampling methods to assess aquatic invertebrate diversity in bromeliads? Hydrobiologia, 649, 293-300.

Kitching R.L. (2000) Food Webs and Container Habitats: The Natural History and Ecology of Phytotelmata. Cambridge University Press, Cambridge.
Invertebrate population dynamics in tank bromeliads

Lecraw R.M., Srivastava D.S. \& Romero G.Q. (2014) Metacommunity size influences aquatic community composition in a natural mesocosm landscape. Oikos, 123, 903-911.

Leroy C., Carrias J.-F., Céréghino R. \& Corbara B. (2016) The contribution of microorganisms and metazoans to mineral nutrition in bromeliads. Journal of Plant Ecology, 9, 241-255.

Leung A.S.L. \& Dudgeon D. (2011) Scales of spatiotemporal variability in macroinvertebrate abundance and diversity in monsoonal streams: detecting environmental change. Freshwater Biology, 56, 1193-1208.

Leung A.S.L., Li A.O.Y. \& Dudgeon D. (2012) Scales of spatiotemporal variation in macroinvertebrate assemblage structure in monsoonal streams: the importance of season. Freshwater Biology, 57, 218-231.

Marino N.A.C., Srivastava D.S. \& Farjalla V.F. (2013) Aquatic macroinvertebrate community composition in tankbromeliads is determined by bromeliad species and its constrained characteristics. Insect Conservation and Diversity, 6, 372-380.

Merritt R.W., Cummins K.W. \& Berg M.B. (2008) An Introduction to Aquatic Insects of North America. Kendall/Hunt Publishing Company, Dubuque.

Petermann J.S., Farjalla V.F., Jocqué M., Kratina P., Macdonald A.A.M., Marino N.A.C. et al. (2015) Dominant predators mediate the impact of habitat size on trophic structure in bromeliad invertebrate communities. Ecology, 96, 428-439.

Poelman E.H. \& Dicke M. (2008) Space use of Amazonian poison frogs: testing the reproductive resource defense hypothesis. Journal of Herpetology, 42, 270-278.

$\mathrm{R}$ Core Team (2015) R: A Language and Environment for Statistical Computing. $\mathrm{R}$ Foundation for Statistical Computing, Vienna. Available at: http://www.R-project. org.

Richardson B.A. (1999) The bromeliad microcosm and the assessment of faunal diversity in a Neotropical forest. Biotropica, 31, 321-336.

Richardson M.J., Richardson B.A. \& Srivastava D.S. (2015) The stability of invertebrate communities in bromeliad phytotelmata in a rain forest subject to hurricanes. Biotropica, 47, 201-207.

Southwood T.R.E. (1977) Habitat, the templet for ecological strategies. Journal of Animal Ecology, 46, 337-365.

Southwood T.R.E. (1988) Tactics, strategies, and templets. Oikos, 52, 3-18.

Spooner D.E. \& Vaughn C.C. (2006) Context-dependent effects of freshwater mussels on stream benthic communities. Freshwater Biology, 51, 1016-1024.

Srivastava D.S. (2006) Habitat structure, trophic structure and ecosystem function: interactive effects in a bromeliad-insect community. Oecologia, 149, 493-504.

Srivastava D.S. \& Bell T. (2009) Reducing horizontal and vertical diversity in a foodweb triggers extinctions and impacts functions. Ecology Letters, 12, 1016-1028. 
Srivastava D.S., Kolasa J., Bengtsson J., Gonzalez A., Lawler S.P., Miller T.E. et al. (2004) Are natural microcosms useful model systems for ecology? Trends in Ecology E Evolution, 19, 379-384.

Stead T.K., Schmid-Araya J.M. \& Hildrew A.G. (2005) Secondary production of a stream metazoan community: does the meiofauna make a difference? Limnology and Oceanography, 50, 398-403.

Stott P. (2016) How climate change affects extreme weather events. Science, 352, 1517.

Sugden A.M. \& Robins R.J. (1979) Aspects of the ecology of vascular epiphytes in Colombian forests, I. The distribution of the epiphyte flora. Biotropica, 11, 173-188.

Talaga S., Dejean A., Carinci R., Gaborit P., Dusfour I. \& Girod R. (2015) Updated checklist of the mosquitoes (Diptera: Culicidae) of French Guiana. Journal of Medical Entomology, 52, 770-782.

Trzcinski M.K., Srivastava D.S., Corbara B., Dézerald O., Leroy C., Carrias J.F. et al. (2016) The effects of food web structure on ecosystem function exceeds those of precipitation. Journal of Animal Ecology, 85, 1147-1160.

Wright S.J. \& Cornejo F.H. (1990) Seasonal drought and leaf fall in a tropical forest. Ecology, 71, 1165-1175.

\section{Supporting Information}

Additional Supporting Information may be found in the online version of this article:

Appendix S1. List of the aquatic invertebrates forming the species pool at our study site.

Appendix S2. Analyses evaluating the pertinence of sampling procedure.

(Manuscript accepted 3 October 2016) 